\title{
IMPLEMENTASI PENDIDIKAN INKLUSI BERBASIS PENGEMBANGAN DIRI DI SEKOLAH ALAM JOGJA GREEN SCHOOL
}

\author{
Baiq Arnika Saadati ${ }^{1}$, Muhamad Sadli ${ }^{2}$ \\ ${ }^{1}$ Fakultas Tarbiyah dan Keguruan UIN Sunan Kalijaga Yogyakarta, ${ }^{2}$ Fakultas Pendidikan UNU NTB \\ Email: ${ }^{1}$ arnikasaadati@gmail.com, ${ }^{2}$ muhamadsadli040414@gmail.com
}

\begin{abstract}
Abstrak: Penelitian ini bertujuan untuk mendeskripsikan dan menganalisis implementasi pendidikan inklusi berbasis pengembangan diri di Jogja Green School. Penelitian ini menggunakan penelitian kualitatif deskriptif dengan pendekatan studi kasus. Teknik pengumpulan data dilakukan dengan wawancara, observasi, dan dokumentasi terhadap kepala sekolah, guru, dan peserta didik. Data dianalisis dengan model interaktif yang terdiri dari reduksi data, penyajian data, dan penarikan kesimpulan. Hasil penelitian menunjukkan bahwa: (1) implementasi pendidikan inklusi di Jogja Green School bertujuan untuk membentuk paradigma warga sekolah maupun warga masyarakat untuk berpikir secara inklusif terhadap segala bentuk perbedaan; (2) penerapan pendidikan inklusi Jogja Green School berbasis pengembangan diri peserta didik dikembangkan dengan membuat program-program yang sesuai dengan minat dan bakat peserta didik; dan (3) dalam mengimplementasikan pendidikan inklusi, Jogja Green School menerapkan metode pembelajaran yang bervariasi dan menyenangkan agar proses pembelajaran berlangsung efektif dan efisien dengan dibantu oleh shadaow teacer atau guru pendamping untuk anak berkebutuhan khusus (ABK).
\end{abstract}

Kata kunci: Pendidikan Inklusi, Pengembangan Diri, Anak Berkebutuhan Khusus.

\section{PENDAHULUAN}

Pendidikan yang dapat mencerdaskan bangsa adalah pendidikan yang terbebas dari segala unsur diskriminasi seperti diskriminasi karena agama, suku, ras, budaya, termasuk diskriminasi terhadap anak yang memiliki kebutuhan khusus. Undang-Undang Nomor 20 Tahun 2003 tentang Sistem Pendidikan Nasional menjelaskan bahwa setiap warga negara berhak memperoleh pendidikan dasar yang bermutu baik bagi yang menderita keterbatasan fisik, mental/intelektual, memiliki bakat istimewa, dan yang tinggal di tempat terpencil. ${ }^{1}$

Selama ini, masyarakat sangat familiar dengan sekolah luar biasa (SLB). SLB merupakan tempat anak-anak berkebutuhan khusus mendapatkan fasilitas pendidikan secara khusus berdasarkan derajat dan jenis kekhususannya. ${ }^{2}$ Namun, kehadiran SLB ternyata bukan menjadi suatu solusi yang tepat bagi pemerataan pendidikan yang bermutu di Indonesia. Kehadiran SLB justru menjadi jurang dikotomi antara sekolah untuk anak normal dan

\footnotetext{
${ }^{1}$ Undang-Undang No. 20 Tahun 2003 tentang Sistem Pendidikan Nasional. Diakses pada tanggal 06 September 2019.

2Indah Permata Darma dan Binhayati Rusyidi, Pelaksanaan Sekolah Inklusi di Indonesia, Jurnal Proiding KS. Riset dan PKM, Volume 2 Nomor 2, h. 223
} 
sekolah untuk anak tidak normal (berkebutuhan khusus) sehingga terjadilah pemetaanpemetaan dan kategorisasi sekolah. Akibatnya, anak berkebutuhan khusus seringkali menjadi sasaran empuk terjadinya diskriminasi, dimarjinalkan, dan tersingkirkan dalam pelbagai aspek kehidupan sosial di masyarakat.

Pendidikan inklusi hadir sebagai salah satu pendidikan alternatif yang dapat mewujudkan pemerataan pendidikan di Indonesia. Pendidikan inklusi merupakan pola layanan pendidikan yang memberikan ruang kepada anak berkebutuhan khusus untuk menerima pendidikan di sekolah-sekolah reguler bersama teman sebayanya. Sekolah memberi wadah kepada para peserta didik di kelas yang sama dari berbagai macam karakteristik dan perbedaan kecerdasan sehingga dapat mengeyam pendidikan secara merata. ${ }^{3}$ Pendidikan inklusi menjadi salah satu bentuk pelaksanaan pendidikan tanpa diskriminasi. Melalui implementasi pendidikan inklusi diharapkan dapat menciptakan generasi bangsa yang dapat berpikir secara inklusif terhadap segala bentuk perbedaan.

Salah satu sekolah dasar yang telah mengimplementasikan pendidikan inklusi adalah sekolah alam Jogja Green School. Secara geografis, sekolah ini terletak di Dusun Jambon RT 04/RW 22 Trihanggo, Kecamatan Gamping Kabupaten Sleman Yogyakarta. ${ }^{4}$ Pendidikan inklusi di Jogja Green School bukanlah sekedar penggabungan ruang belajar bagi anak nonberkebutuhan khusus (normal) dengan anak yang berkebutuhan khusus. Namun, sekolah inklusi diartikan sebagai sekolah yang berkomitmen, mengakomodasi, dan memfasilitasi ragam perbedaan, termasuk latar belakang keluarga, gaya belajar, minat, maupun potensi dan kapasitas peserta didik maupun guru. Penghargaan terhadap perbedaan merupakan komitmen yang dijunjung tinggi oleh Jogja Green School. Pendidikan inklusi yang diterapkan di sekolah ini adalah berbasis pada pengembangan diri peserta didik. ${ }^{5}$

Pengembangan diri adalah kegiatan yang bertujuan memberikan kesempatan kepada peserta didik untuk mengembangkan dan mengekspresikan diri sesuai dengan kebutuhan,

${ }^{3}$ Hasan Baharun dan Robiatul Awwaliyah, Pendidikan Inklusi Bagi Anak Berkebutuhan Khusus Dalam Perspektif Epistemologi Islam, Jurnal Modeling, Volume, 5, Nomor 1, Maret 2018), hlm. 59-60.

${ }_{4}^{4}$ Data diperoleh dari blog Jogja Green School, dalam http://www.yogya greeenschool.com/, diakses pada tanggal 5 September 2019.

5Jogja Green School, Observasi, 12 September 2019.

118 Copyright $\odot$ el-Midad : Jurnal PGMI 2019 
bakat, dan minat. ${ }^{6}$ Program-program pengembangan diri yang disusun bertujuan untuk memberikan berbagai bentuk pelatihan yang berkenaan dengan pengembangan potensi peserta didik dalam berbagai bidang serta untuk meningkatkan kecakapan hidup (life skill) serta kemandirian yang disesuaikan dengan kebutuhan khusus peserta didik. Program pengembangan diri di Jogja Green School dinamakan kelas minat.

Kelas minat merupakan jam pembelajaran yang mengakomodir pendalaman atas minat bakat peserta didik. Peserta didik diperkenankan memilih kelas sesuai minat bakatnya, dan dapat berpindah-pindah hingga menemukan kecocokan dengan potensi diri masingmasing.

\section{LANDASAN TEORI}

\section{Pendidikan Inklusif}

Pendidikan inklusif merupakan suatu sistem layanan pendidikan khusus yang mensyaratkan agar semua anak baik yang berkebutuhan khusus maupun anak yang tidak berkebutuhan khusus mendapat layanan pendidikan di sekolah yang terdekat dengan rumahnya agar dapat mengeyam pendidikan bersama dengan teman-teman sebayanya. Masyarakat yang melaksanakan pendidikan inklusif memiliki suatu keyakinan bahwa hidup dan belajar bersama merupakan ssuatu metode hidup terbaik karena dengan adanya pendidikan inklusif ini dapat menerima dan merespon setiap kebutuhan individual anak. ${ }^{7}$

Landasan filosofis implementasi pendidikan inklusif di Indonesia adalah falsafah negara kita yaitu pancasila. Filsafat ini sebagai wujud pengakuan kebinekaan manusia yaitu kebinekaan secara vertikal dan horizontal. Kebinekaan vertikal merupalan kebinekaan terhadap perbedaan intelektual, kekuatan fisik, kemampuan finansial, perbedaan emosi, dan sebagainya, sedangkan kebinekaan horizontal merupakan perbedaan suku, ras, bahasa, budaya, agama, tempat tinggal, daerah, dan sebagainya. ${ }^{8}$ Dengan demikian, dapat

${ }^{6}$ Muhamad Takdir Ilahi, Revitalisasi Pendidikan Berbasis Moral, (Maguwoharjo, Ar-Ruzz Media, 2012), hlm. 100

${ }^{7}$ N. Praptiningrum, Fenomena Penyelenggaraan Pendidikan Inklusif Bagi Anak Berkebutuhan Khusus, dalam Jurnal Pendidikan Khusus, Voleme 7, Nomor 2 Tahun 2010

${ }^{8}$ Abdul Rahim, Pendidikan Inklusif Sebagai Strategi Dalam Mewujudkan Pendidikan Untuk Semua, dalam Jurnal Trihayu, Voleme 3, Nomor 1 Tahun 2016, hlm. 69 
disimpulkan bahwa pendidikan inklusif merupakan suatu layanan pendidikan yang diberikan kepada anak-anak berkebutuhan khusus dan anak-anak yang non berkebutuhan khusus agar dapat belajar secara bersama-sama di kelas reguler tanpa ada pemisahan. Dengan demikian, setiap individu memperoleh hak yang sama untuk mengeyam pendidikan.

Adapun landasan yuridis yang dijadikan sebagai dasar hukum pelaksanaan pendidikan inklusi adalah: (a) Konvensi PBB tentang Hak Anak Tahun 1989. (b) Deklarasi pendidikan untuk semua di Thailand Tahun 1990. (c) Kesepakatan Salamanka tentang Pendidikan Inklusi Tahun 1994. (d) UU. No 4 tentang Penyandang Cacat Tahun 1997. (e) UU No. 23 tentang Perlindungan Hak Anak Tahun 2003. (f) PP No. 19 tentang Standar Pendidikan Inklusi Tahun 2004. (g) Deklarasi Bandung tentang Menuju Pendidikan Inklusi Tahun 2004. (h) Rekomendasi Bukittinggi 2005. ${ }^{9}$

\section{Pengembangan Diri}

Menurut Marwani pengembangan diri merupakan suatu proses peningkatan kemampuan, potensi, kepribadian, dan sosial emosional seseorang agar terus tumbuh dan berkembang. ${ }^{10}$ Dengan demikian, dapat dikatakan bahwa pengembangan diri berarti mengembangkan bakat yang dimiliki, mewujudkan impian-impian, meningkatkan rasa percaya diri melalui proses by eksperiencess (dari pengalaman), menerima umpan balik dari orang lain, melatih kepekaan terhadap diri sendiri maupun orang lain, dan mendalam kesadaran. ${ }^{11}$

Dalam Permendiknas Nomor 22 Tahun 2006 tentang Standar Isi menjelaskan bahwa perlunya disusun dan dilaksanakan program pengembangan diri yang bertujuan memberikan kesempatan kepada peserta didik untuk mengembangkan dan mengekpresikan diri sesuai dengan kebutuhan, bakat, dan minat peserta didik yang disesuaikan dengan kondisi sekolah. ${ }^{12}$

Dari pengertian tersebut, dapat disimpulkan bahwa pengembangan diri merupakan suatu aktivitas yang bertujuan untuk mengembangkan segala kemampuan dan potensi yang

\footnotetext{
${ }^{9}$ Mukhtar Latif, Dkk, Pendidikan Anak Usia Dini, (Jakarta: Kencana Prenadamedia Group, 2013), hlm. 318

${ }^{10}$ Marmawi, Persamaan Gender dalam Pengembangan Diri, dalam Jurnal Pendidikan, hlm. 176

${ }^{11}$ Taris Tarmudji, Pengembangan Diri, ( Yogyakarta: Liberty Yogyakarta, 1998), hlm. 29

12Peraturan Menteri Pendidikan Nasional Republik Indonesia Nomor 22 Tahun 2006 tentang Standar Isi untuk Satuan Pendidikan Dasar dan Menengah.
} 
dimiliki oleh peserta didik seoptimal mungkin sehingga dapat meningkatkan segala kemampuan dan potensinya. Selain itu, kegiatan pengembangan diri dapat menjadikan peserta didik lebih percaya diri serta peserta didik dapat mengenali potensi yang dimilikinya.

\section{METODE PENELITIAN}

Metode penelitian yang digunakan pada penelitian ini adalah penelitian kualitatif deskriptif. Metode penelitian kualitatif merupakan suatu metode penelitian yang bertujuan untuk melihat suatu fenomena secara mendalam. ${ }^{13}$ Teknik pengumpulan data yang digunakan adalah observasi, interview, dan dokumentasi.

Observasi merupakan pengamatan dan pencatatan terhadap suatu objek yang dilakukan dengan sistematis mengenai fenomena yang diteliti. Observasi yang dilakukan pada penelitian ini adalah observasi langsung, yaitu peneliti langsung mengamati dan mencatat fenomena yang diamati yaitu Implementasi Pendidikan Inklusi di Jogja Green School. Interview merupakan salah satu teknik pengumpulan data dengan proses tanya jawab secara lisan dan saling berhadapan secara fisik. Jenis interview yang digunakan pada penelitian ini adalah interview tak terpimpin, yaitu suatu proses interview yang tidak dikendalikan oleh suatu pedoman yang telah disiapkan oleh interviewer sehingga proses interview berjalan bebas (free talk). Sementara, dokumentasi digunakan untuk memperoleh data berupa foto, video, catatan pribadi, buku harian, dan lain sebagainya. ${ }^{14}$ Adapun analisis data yang digunakan pada penelitian ini terdiri dari empat tahap yaitu proses pengumpulan data, reduksi data, penyajian data, dan penarikan kesimpulan.

\section{HASIL PENELITIAN DAN PEMBAHASAN}

\section{Tujuan Pendidikan Inklusi di Jogja Green School}

Pendidikan inklusi di Indonesia secara resmi diartikan sebagai sistem layanan pendidikan yang mengikutsertakan anak berkebutuhan khusus belajar bersama dengan 67

13Rully Indrawan dan Poppy Yaniwati, Metodelogi Penelitian (Bandung: PT Refika Aditama, 2016), hlm.

${ }^{14}$ Sukandarrumidi, Metodelogi Penelitian, (Yogyakarta, UGM Press, 2012), hlm. 69-101 
anak sebayanya di sekolah reguler yang terdekat dengan tempat tinggal peserta didik. Menurut O’Neil model pendidikan inklusi berupaya memberikan kesempatan yang sama kepada semua anak, agar memperoleh kesempatan belajar. Pendidikan inklusi tidak berfokus kepada kekurangan dan keterbatasan anak, tetapi mengacu pada kelebihan dan potensi yang dimiliki anak agar lebih berkembang. ${ }^{15}$

Pendidikan inklusi merupakan perkembangan terkini dari model pendidikan bagi anak special need dengan memberikan kesempatan belajar bersama-sama tanpa memandang suatu perbedaan dan kesulitan dalam diri anak. ${ }^{16}$ Dengan demikian, dapat disimpulkan bahwa pendidikan inklusi merupakan pendidikan yang bertujuan untuk menerima semua anak tanpa membeda-bedakan anak dari berbagai latar belakangnya, sehingga pendidikan berlangsung secara merata tanpa diskriminasi dan dikotomi.

Sementara tujuan diselenggarakannya pendidikan inklusi adalah untuk memaksimalkan seluruh potensi yang dimiliki peserta didik yang berkebutuhan khusus sehingga terlibat dalam kehidupan sekolah secara menyeluruh. ${ }^{17}$ Pendidikan inklusi di Jogja Green School berjalan seperti sekolah reguler pada umumnya. Anak yang normal dan memiliki kebutuhan khusus ditempatkan di kelas yang sama, akan tetapi anak berkebutuhan khusus (ABK) memiliki guru pendamping khusus yang disebut sebagai shadow teacher. Shadow teacher merupakan guru yang bertugas untuk membantu guru kelas dalam mendampingi peserta didik yang ABK di dalam kelas, sehingga proses pembelajaran berjalan secara efektif dan efisien. Adapun tujuan Pendidikan inklusi di Jogja Green School adalah sebagai berikut: ${ }^{18}$

${ }^{15}$ Muhammad Takdir Ilahi, Pendidikan Inklusi Konsep dan Aplikasi, (Maguwoharjo, Ar-Ruzz Media, 2013), hlm. 26-28

${ }^{16}$ Ermawati, Mengenal Lebih Jauh Sekolah Inklusi (Bandung: Refika Aditama, 2008), hlm. 22

${ }^{17}$ Smith, J. D, Inklusi:Sekolah Ramah untuk Semua, (Bandung: Nuasa, 2009), hlm. 45

${ }^{18}$ Kepala Sekolah Jogja Green School, Wawancara, 18 September 2019. 


\section{Tabel. 1 Tujuan Pendidikan Inklusi di Jogja Green School}

\begin{tabular}{|c|c|c|c|c|}
\hline No & $\begin{array}{c}\text { Bagi anak } \\
\text { berkebutuhan } \\
\text { khusus }\end{array}$ & $\begin{array}{l}\text { Bagi anak tanpa } \\
\text { kebutuhan khusus }\end{array}$ & Bagi guru & Bagi keluarga \\
\hline 1. & $\begin{array}{l}\text { Bebas dari stigma } \\
\text { negatif }\end{array}$ & $\begin{array}{l}\text { Belajar mengenal } \\
\text { dan menghargai } \\
\text { keunikan maupun } \\
\text { keterbatasan teman }\end{array}$ & $\begin{array}{l}\text { Menambah } \\
\text { pengetahuan } \\
\text { tentang ragam } \\
\text { karakter peserta } \\
\text { didik }\end{array}$ & $\begin{array}{l}\text { Meningkatkan } \\
\text { penghargaan dan } \\
\text { penerimaan } \\
\text { terhadap setiap anak } \\
\text { juga guru yang } \\
\text { mengelola dinamika } \\
\text { kelas }\end{array}$ \\
\hline 2. & $\begin{array}{l}\text { Anak mempunyai } \\
\text { rasa percaya diri }\end{array}$ & $\begin{array}{l}\text { Dapat } \\
\text { mengembangkan } \\
\text { keterampilan sosial }\end{array}$ & $\begin{array}{l}\text { Mengetahui titik } \\
\text { kekuatan dan } \\
\text { kelemahan } \\
\text { peserta didiknya }\end{array}$ & $\begin{array}{l}\text { Lebih terlibat dan } \\
\text { kreatif berkontribusi } \\
\text { dalam } \\
\text { perkembangan anak }\end{array}$ \\
\hline 3. & $\begin{array}{l}\text { Anak mendapatkan } \\
\text { peluang untuk } \\
\text { beradaptasi dengan } \\
\text { teman sebayanya } \\
\text { yang non ABK. }\end{array}$ & $\begin{array}{l}\text { Belajar berempati } \\
\text { pada permasalahan } \\
\text { teman }\end{array}$ & $\begin{array}{l}\text { Lebih kreatif } \\
\text { dalam mengajar, } \\
\text { mendidik dan } \\
\text { mengelola kelas }\end{array}$ & \\
\hline 4. & $\begin{array}{l}\text { Anak memiliki } \\
\text { kesiapan } \\
\text { menghadapi } \\
\text { kehidupan nyata }\end{array}$ & $\begin{array}{l}\text { Belajar peduli dan } \\
\text { membantu teman } \\
\text { yang membutuhkan } \\
\text { bantuan }\end{array}$ & & \\
\hline 5 & $\begin{array}{l}\text { Anak memiliki } \\
\text { kesiapan } \\
\text { menghadapi } \\
\text { kehidupan nyata }\end{array}$ & & & \\
\hline
\end{tabular}

\section{Metode Pembelajaran di Jogja Green School}

Jogja Green School berprinsip pada transdicplinary, yang memberi pondasi pada peserta didik untuk berkembang dalam hal mengambil keputusan dan menyelesaikan masalah yang dihadapi (problem solver capacity). Kelompok mata pelajaran di Jogja Green School terbagi menjadi dua, yaitu kelompok A dan B. Kelompok A, antara lain; Pendidikan Pancasila dan Kewarganegaraan, Pendidikan Agama, Bahasa Indonesia, Matematika, Ilmu Pengetahuan Alam (IPA), Ilmu Pengetahuan Sosial (IPS), dan Bahasa Inggris. Kelompok B, antara lain; Seni Budaya dan Keterampilan (termasuk muatan lokal) dan Pendidikan Jasmani Olahraga Kesehatan (termasuk muatan lokal). ${ }^{19}$

${ }^{19}$ Waka Kurikulum, Wawancara, 13 September 2019. 
Metode pembelajaran di Jogja Green School menggunakan pendekatan yang menghargai ragam kecenderungan gaya belajar dan kecerdasan majemuk peserta didik. Ragam gaya belajar tersebut antara lain; visual, auditori dan kinestetik. Visual learners adalah anak yang potensial mempelajari suatu hal melalui penglihatan, membutuhkan alat peraga atau gambar-gambar untuk membangun/menstimulasi pemahamannya. Auditory learners adalah anak yang cenderung mengandalkan pendengaran untuk menangkap dan mengingat informasi maupun membangun pemahaman. Kinesthetic learners adalah anak yang cenderung membutuhkan sentuhan dan gerak untuk menangkap dan mengingat informasi serta mempelajari suatu hal. Ragam kecerdasan (menurut Howard Gardner) antara lain:20

a. Kecerdasan logika-matematika

Seseorang dengan kecenderungan mampu berpikir deduktif maupun induktif, mampu memecahkan masalah dengan pola berpikir logis, mampu memahami dan menganalisis pola-pola angka. Biasanya menyenangi berpikir konseptual dan mengkategorisasi.

b. Kecerdasan linguistik

Seseorang dengan kecenderungan mampu menggunakan kata atau kalimat baik lisan maupun tulisan secara baik, untuk mengekspresikan gagasannya. Biasanya menyenangi membuat karya tulis, seperti berita, puisi, cerpen, novel. Biasanya pula, lebih berminat mempelajari ragam bahasa.

c. Kecerdasan musikal

Seseorang dengan kecenderungan mampu \& peka terhadap nada atau ritme (bentukbentuk bahasa nonverbal). Biasanya menyenangi dunia musik dan tarik suara. Anak lebih berminat mengekspresikan diri dan gagasan melalui lagu atau instrumen musik.

d. Kecerdasan visual spasial

Seseorang dengan kecenderungan mampu berimajinasi dan mencipta karya dalam bentuk/ruang. Biasanya menyenangi kegiatan menggambar, baik dua maupun tiga dimensi. e. Kecerdasan kinestetik

Seseorang dengan kecenderungan mampu mengekspresikan diri dan gagasannya melalui aktivitas gerak. Biasanya anak menaruh minat pada bidang olahraga. 
f. Kecerdasan interpersonal

Seseorang dengan kecenderungan peka pada perasaan orang lain. Anak cenderung pandai dalam berelasi atau bersosialisasi. Anak tipe yang mudah bersahabat dan simpatik pada orang lain. Biasanya memiliki banyak teman dan relasi yang luas, juga pandai memimpin mengorganisir maupun mengelola konflik.

g. Kecerdasan intrapersonal

Seseorang yang cenderung peka terhadap emosi di dalam dirinya, termasuk kekuatan dan kelemahan di dalam diri. Biasanya anak yang cenderung kuat dalam refleksi diri dan spiritualitas.

h. Kecerdasan naturalis

Seseorang yang cenderung gemar dan peka pada lingkungan alam. Biasanya anak sangat berminat untuk observasi maupun eksplorasi hal-hal yang ada di alam; seperti hewan, tumbuhan, sungai, laut, danau, gunung dan lain sebagainya.

\section{Implementasi Pendidikan Inklusi Berbasis Pengembangan Diri di Jogja Green School}

Implementasi pendidikan inklusi di Jogja Green School menekankan pada pengembangan diri peserta didik yang berpsinsip pada penumbuhan budi pekerti pada anak. ${ }^{21}$ Pengembangan diri adalah kegiatan yang bertujuan memberikan kesempatan kepada peserta didik untuk mengembangkan dan mengekspresikan diri sesuai dengan kebutuhan, bakat, dan minat. ${ }^{22}$

Program-program pengembangan diri yang disusun bertujuan untuk memberikan berbagai bentuk pelatihan yang berkenaan dengan pengembangan potensi peserta didik dalam berbagai bidang serta untuk meningkatkan kecakapan hidup (life skill) serta kemandirian yang disesuaikan dengan kebutuhan khusus peserta didik. Program pengembangan diri di Jogja Green School dinamakan kelas minat.

${ }^{21}$ Nurul Zuriah, Pendidikan Moral dan Budi Pekerti dalam Perspektif Perubahan, (Jakarta: Bumi Aksara, 2007), hlm. 124

${ }^{22}$ Muhamad Takdir Ilahi, Revitalisasi Pendidikan Berbasis Moral, (Maguwoharjo, Ar-Ruzz Media, 2012), hlm. 100 
Kelas minat merupakan jam pembelajaran yang mengakomodir pendalaman atas minat bakat peserta didik sehingga diperkenankan memilih kelas sesuai minat bakatnya, dan dapat berpindah-pindah hingga menemukan kecocokan dengan potensi diri masing-masing. Adapun kelas minat yang ada di Jogja Green School terdiri dari: kelas minat penelitian, kelas minat fotografi, kelas minat memasak atau cooking class kelas minat berkebun dan kelas minat teater.

\section{a. Kelas Penelitian}

Kelas minat penelitian diikuti oleh peserta didik (ABK dan Non ABK) serta memiliki bakat dan ketertarikan dalam bidang sains dan lingkungan (environment). Kelas minat penelitian bertujuaan untuk memberikan pemahaman secara langsung kepada peserta didik tentang berbagai hal tentang sains dan lingkungan (environment). Dalam proses pembelajaran, guru menekankan pada penerapan metode learning by doing dan learning by experiences agar apa yang dipelajari oleh peserta didik bisa dipahami dengan bermakna. Berikut contoh kegiatan kelas penelitian di Jogja Green Schoo.23

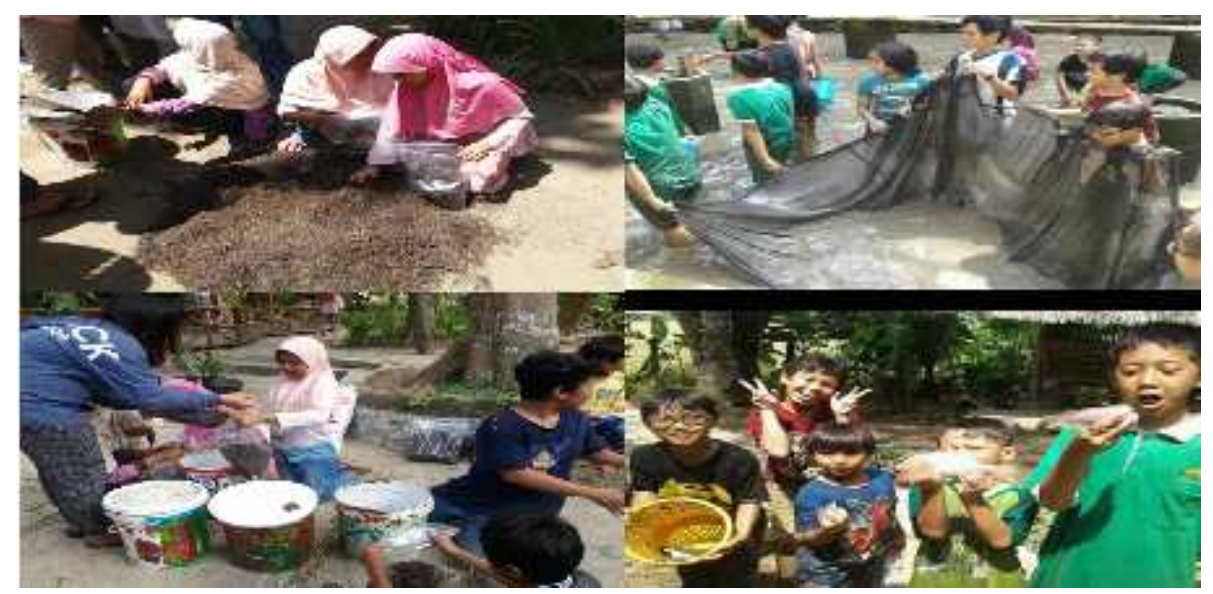

Gambar. 1 Kegiatan Praktek Membuat Pupuk Kompos dan Memanen Hasil Budidaya Ikan Nila. 
Adapun aspek pengetahuan dan keterampilan yang diharapkan dimiliki oleh peserta didik setelah mengikuti kelas ini adalah sebagai berikut: ${ }^{24}$

Tabel. 2 Aspek Pengetahuan dan Keterampilan Kelas Minat Penelitian

\begin{tabular}{|l|l|l|}
\hline No & Aspek Pengetahuan & Aspek Keterampilan \\
\hline 1. & $\begin{array}{l}\text { Mengenalkan perkembangbiakan } \\
\text { Lumbricus sp (Berternak cacing tanah) } \\
\text { dan berternak ikan nila dan lele }\end{array}$ & $\begin{array}{l}\text { Praktek beternak cacing tanah, ikan nila } \\
\text { dan lele, pemantauan hasil, dan penulisan } \\
\text { laporan }\end{array}$ \\
\hline 2. & $\begin{array}{l}\text { Mengenalkan tentang telur rasa nano- } \\
\text { nano }\end{array}$ & $\begin{array}{l}\text { Pembuatan telur nano-nano ada rasa asin, } \\
\text { asam, manis dan pedas, cek hasil telur, dan } \\
\text { penulisan laporan }\end{array}$ \\
\hline 3. & $\begin{array}{l}\text { Mengenalkan tentang salah satu cara } \\
\text { perkembangbiakan tanaman dengan } \\
\text { Sambung Pucuk AdeniummixCollor }\end{array}$ & $\begin{array}{l}\text { Praktek sambung pucuk Adenium } \\
\text { mixCollor, pengamatan hasil, , dan } \\
\text { penulisan laporan }\end{array}$ \\
\hline 4. & $\begin{array}{l}\text { Mengenalkan tentang bunga Anyelir } \\
\text { dan Mawar }\end{array}$ & $\begin{array}{l}\text { Praktek pewarnaan bunga Anyelir dan } \\
\text { Mawar, penulisan hasil laporan. }\end{array}$ \\
\hline 5. & $\begin{array}{l}\text { Mengenalkan tentang Jeli Carsen } \\
\text { Muntingia Lalabura L) sebagai } \\
\text { peningkat stamina }\end{array}$ & $\begin{array}{l}\text { Praktek pembuatan jeli carsen, penulisan } \\
\text { hasil laporan, dan presentasi }\end{array}$ \\
\hline 6. & $\begin{array}{l}\text { Mengenal kompos pribadi Jogja Green } \\
\text { School (Bank Kompos) }\end{array}$ & $\begin{array}{l}\text { Praktek pembuatan kompos, pemantauan, } \\
\text { penulisan hasil laporan, pemanenan } \\
\text { kompos }\end{array}$ \\
\hline 7. & $\begin{array}{l}\text { Persiapan Pameran } \\
\text { Bank komppos, peternakan cacing, } \\
\text { mawar/ bunga mix warna, sambung pucuk, } \\
\text { dan laporan hasil kegiatan. }\end{array}$ \\
\hline
\end{tabular}

\section{b. Kelas Minat Fotografi}

Kelas minat fotografi bertujuan untuk mengenalkan pengetahuan kepada peserta didik tentang teknik pengambilan objek bergerak dan benda yang dibuat bergerak. Contoh keterampilan yang dipraktikkan adalah mengambil gambar transportasi dan mengambil gambar benda yang dibuat bergerak. contoh: batu, bola dan benda lainnya yang bisa dilempar tangkap. Selain itu, peserta didik juga diperkenalkan untuk mengambil gambar hewan besar. contoh: sapi, kambing, dan kerbau, juga praktik mengambil gambar hewan kecil contoh: belalang, kupu-kupu, kumbang, dan semut. ${ }^{25}$

${ }^{24}$ Jogja Green School, Dokumentasi, 03 Oktober 2019

${ }^{25}$ Bapak Damas, Wawancara, 19 September 2019. 
Kelas minat fotografi diikuti oleh seluruh anak yang ada di Jogja Green School mulai dari Level 1-Level 6 dan diperuntukkan bagi anak yang memiliki minat dan bakat untuk menjadi seorang fotografer. Kelas minat fotografi dilaksanakan satu kali dalam seminggu yaitu pada hari Kamis pukul 12:00-01:30. Guru yang mengajar di kelas minat fotografi adalah guru yang profesioanal di bidang fotografi. ${ }^{26}$

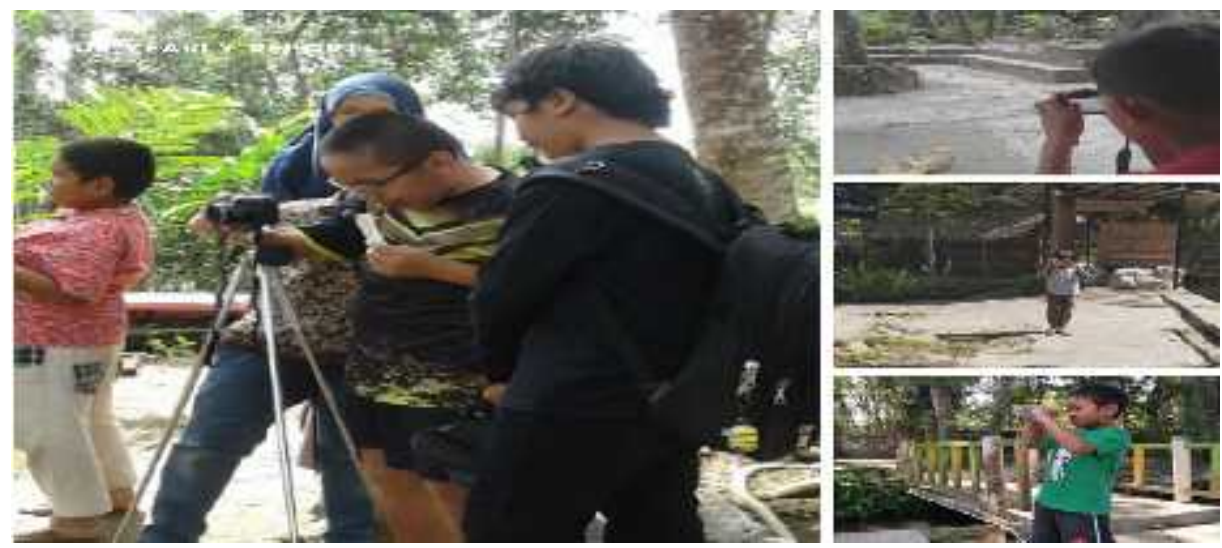

Gambar. 2 Kegiatan Praktik Kelas Minat Fotografi

\section{c. Kelas Memasak}

Kelas minat memasak bertujuan untuk memberikan pengetahuan dan keterampilan kepada seluruh peserta didik (ABK dan Non-ABK) tentang macam-macam masakan yang dapat diolah dari berbagai macam buah dan sayuran. Kelas memasak dilaksanakn satu kali dalam satu minggu yaitu setiap hari Kamis pukul 12:00-01:30. Untuk menilai keterampilan peserta didik dalam memasak, Jogja Green School setiap satu kali semester melakukan kegiatan market day. Market day merupakan even yang diselenggarakan untuk mengajarkan para peserta didik untuk belajar dan mengalami proses jual beli produk yang dimiliki secara langsung.

${ }^{26}$ Jogja Green School, Observasi, 19 September 2019. 




Gambar. 3 Kegiatan Market Day Anak-Anak (Cooking Class)

Adapun aspek pengetahuan dan keterampilan yang harus dicapai oleh peserta didik pada kelas minat memasak adalah sebagai berikut: ${ }^{27}$

Tabel. 3 Aspek Pengetahuan dan Keterampilan Kelas Minat Memasak

\begin{tabular}{|l|l|l|}
\hline No & Aspek Pengetahuan & Aspek Keterampilan \\
\hline 1. & $\begin{array}{l}\text { Mengenalkan berbagai macam } \\
\text { masakan dengan bahan dasar buah }\end{array}$ & $\begin{array}{l}\text { Menjelaskan berbagai macam } \\
\text { jenis buah-buahan, praktek } \\
\text { membuat masakan dengan } \\
\text { bahan dasar buah-buahan } \\
\text { contoh: sate buah coklat, dan } \\
\text { lotis }\end{array}$ \\
\hline 2. & $\begin{array}{l}\text { Mengenalkan berbagai macam } \\
\text { masakan dengan bahan dasar sayur }\end{array}$ & $\begin{array}{l}\text { Menjelaskan berbagai macam } \\
\text { jenis sayuran, praktik membuat } \\
\text { masakan dengan bahan dasar } \\
\text { sayuran }\end{array}$ \\
\hline 3. & Mengenalkan berbagai kudapan & $\begin{array}{l}\text { Praktik membuat kudapan } \\
\text { contoh: pisang goreng, klepon }\end{array}$ \\
\hline 4. & $\begin{array}{l}\text { Mengenalkan berbagai macam jenis } \\
\text { kue }\end{array}$ & $\begin{array}{l}\text { Praktik membuat kue contoh: kue } \\
\text { bolu, kue kukus. }\end{array}$ \\
\hline
\end{tabular}

\section{d. Kelas Berkebun}

Kelas berkebun bertujuan untuk memberikan kesempatan bagi anak melihat langsung proses pertumbuhan tanaman baik dari mulai menanam, merawat, menjaga hingga

${ }^{27}$ Jogja Green School, Dokumentasi, 20 September 2019. 
memetik hasilnya untuk dinikmati bersama. Secara karakter, anak diajarkan untuk merawat, menjaga serta menyayangi ciptaan Tuhan. Secara ilmu, anak mengamati langsung proses pertumbuhan tanaman serta pemanfaatannya. Kelas berkebun diikuti oleh seluruh peserta didik mulai dari level 1 - level 6. Kegiatan berkebun dilaksanakan setiap hari Rabu pukul 08:00-09:00 yang didampingi oleh guru kelas masing-masing. Adapun yang ditanam adalah berbagai macaam sayur-sayuran seperti kangkung, sawi, tomat, bayam, tomat, cabai, terong, dan lai-lain.

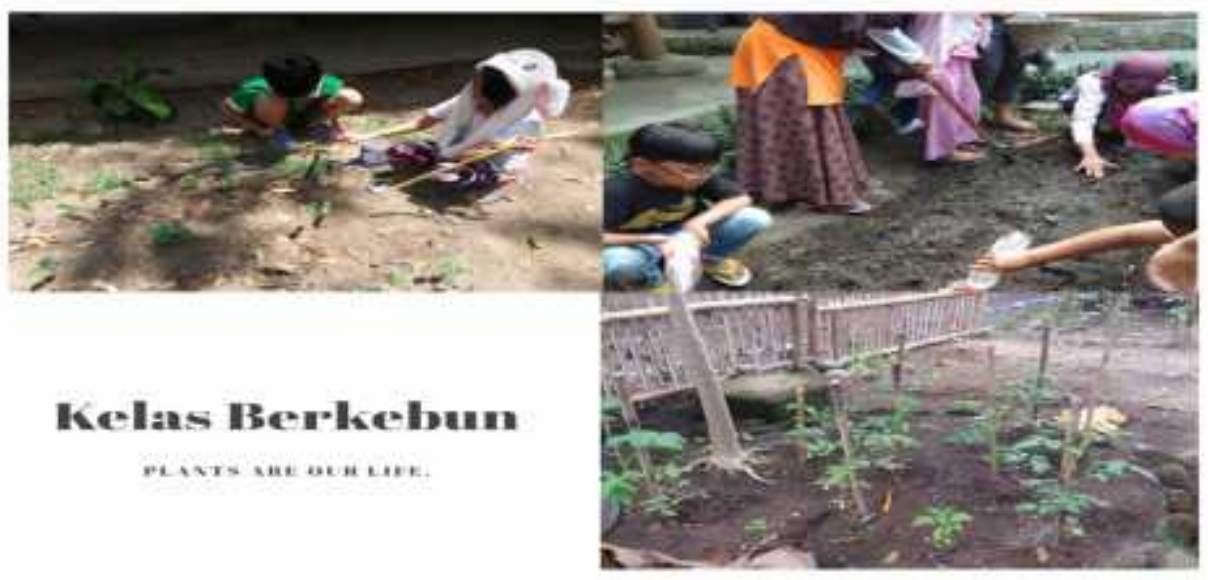

\section{Gambar. 4 Kegiatan Menanam dan Merawat Tanaman}

\section{e. Kelas Teater}

Kelas teater bertujuan untuk melatih anak untuk memerankan berbagai karakter dan melatih rasa percaya diri peserta didik di depan umum pementasan operet anak. Selain itu, anak juga diperkenalkan dan dilatih untuk mempraktekkan gerak dan tari dalam pementasan operet anak. Adapun karakter yang diharapkan dapat terbentuk pada kegiatan ini adalah anak mampu menerapkan kerjasama dalam tim baik saat latihan maupun saat tampil di pementasan operet anak. 28

Seperti kelas minat lainnya, kelas teater juga dilaksanakan satu kali dalam seminggu yaitu setiap hari kamis di ruang pendopo atau ruang seni dan budaya Jogja Green School. Untuk melatih kepercayaan diri, peserta didik juga diberikan kesempatan untuk tampil di luar sekolah jika ada perlombaan-perlombaan yang dilaksanakan. ${ }^{29}$

${ }^{28}$ Bapak Nina, Wawancara, 26 September 2019.

${ }^{29}$ Jogja Green School, Dokumentasi, 26 September 2019. 


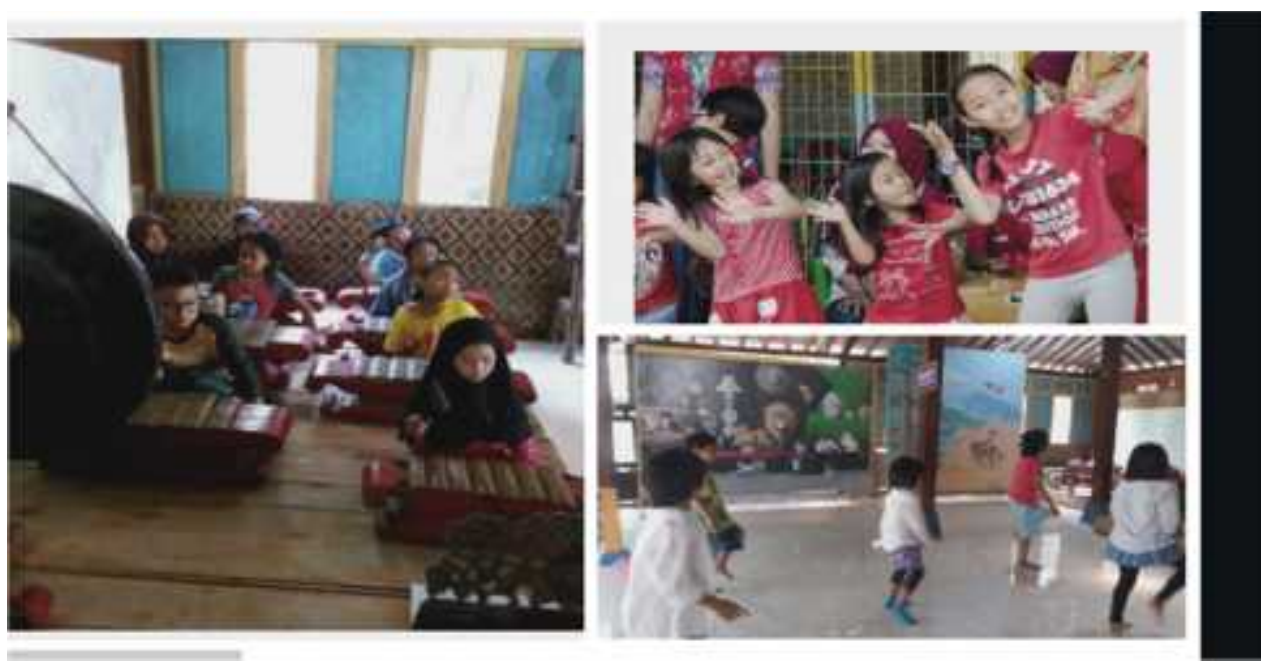

Gambar. 5 Kegiatan Kelas Teater

\section{PENUTUP}

\section{Simpulan}

Berdasarkan hasil analisis tentang implementasi pendidikan inklusif di Jogja Green School dapat disimpulkan bahwa implementasi pendidikan inklusi di jogja green school bertujuan untuk membentuk paradigma warga sekolah maupun warga masyarakat untuk berpikir secara inklusif terhadap segala bentuk perbedaan. Penerapan pendidikan inklusi Jogja Green School menekankan pada pengembangan diri peserta didik yang berprinsip pada pembentukan budi pekerti. Pengembangan diri dikembangkan dengan membuat programprogram yang sesuai dengan minat dan bakat peserta didik seperti kelas minat penelitian, kelas minat memasak, kelas minat potografi, kelas minat teater, dan kelas minat berkebun.

Dalam mengimplementasikan pendidikan inklusi diJogja Green School menerapkan metode pembelajaran yang berpariatif dan menyenangkan agar proses pembelajaran berlangsung efektif dan efisien.Untuk membantu guru kelas, Jogja Green School memiliki guru pendamping atau teacher shadow yang mendampingi anak-anak yang berkebutuhan khusus $(\mathrm{ABK})$.

\section{Saran}

Implementasi pendidikan inklusi sudah berlangsung dengan baik di Jogja Geen School dan perlu dipertahankan, bahkan ditingkatkan kembali untuk mendapatkan hasil yang lebih 
maksimal. Selain itu, guru pendamping maupun guru kelas harus lebih berkomunikasi secara intensif terkait dengan perkembangan peserta didik yang ada dikelas. Kemudian kualifikasi guru pendamping juga harus diperketat, sehingga peserta didik yang ABK mendapatkan guru pendamping yang sesuai dengan kebutuhannya.

\section{DAFTAR PUSTAKA}

Abdul Rahim, Pendidikan Inklusif Sebagai Strategi Dalam Mewujudkan Pendidikan Untuk Semua, dalam Jurnal Tribayu, Voleme 3, Nomor 1 Tahun 2016.

Ermawati, Mengenal Lebih Jauh Sekolah Inklusi Bandung: Refika Aditama, 2008.

Hasan Baharun dan Robiatul Awwaliyah, Pendidikan Inklusi bagi Anak Berkebutuban Khusus dalam Perspektif Epistemologi Islam, Jurnal Modeling, Volume, 5, Nomor 1, Maret 2018.

Indah Permata Darma dan Binhayati Rusyidi, Pelaksanaan Sekolab Inklusi di Indonesia, dalam Jurnal Prosiding KS. Riset dan PKM, Volume 2 Nomor 2.

Jogja Green School . http://www.yogya greeenschool.com/, diakses pada tanggal. 5 September 2019.

Muhamad Takdir Ilahi, Revitalisasi Pendidikan Berbasis Moral, Maguwoharjo, Ar-Ruzz Media, 2012 , Pendidikan Inklusi Konsep dan Aplikasi, Maguwoharjo, Ar-Ruzz

Media, 2013.

Mukhtar Latif, dkk, Pendidikan Anak Usia Dini, Jakarta: Kencana Prenadamedia Group, 2013

Nurul Zuriah, Pendidikan Moral dan Budi Pekerti dalam Perspektif Perubahan, Jakarta: Bumi Aksara, 2007.

Rully Indrawan dan Poppy Yaniwati, Metodelogi Penelitian Bandung: PT Refika Aditama, 2016.

Sukandarrumidi, Metodelogi Penelitian, Yogyakarta, UGM Press, 2012.

Smith, J. D, Inklusi:Sekolah Ramah untuk Semua, Bandung: Nuasa, 2009.

Taris Tarmudji, Pengembangan Diri, Yogyakarta: Liberty Yogyakarta, 1998.

Undang-Undang No. 20 Tahun 2003 tentang Sistem Pendidikan Nasional. Diakses pada tanggal 06 September 2019. 